\title{
Girls with virilisation in childhood: a diagnostic protocol for investigation
}

\author{
M E Street, A Weber, C Camacho-Hübner, L A Perry, C E Brain, A M Cotterill, \\ M O Savage
}

\begin{abstract}
Aim-To analyse critically a protocol for the investigation of girls presenting with virilisation in childhood.

Methods-Twenty five girls aged 1.6-8.7 years with features of virilisation were evaluated. Twenty four had presented with pubic hair, eight with axillary hair, seven with facial acne, four with clitoromegaly, and 10 with tall stature. They underwent clinical assessment (height, weight, height velocity, staging of puberty, physical examination for acne, body odour, and clitoromegaly) and laboratory assessment comprising basal concentrations of cortisol, $17 \mathrm{OH}$-progesterone (17 OHP), androstenedione, dehydroepiandrosteronesulphate (DHEAS), testosterone, and oestradiol. The above steroids were also measured during the short synacthen test ( $0.25 \mathrm{mg}$ intramuscularly) in 16 subjects and low dose dexamethasone suppression tests $(0.5 \mathrm{mg}$ at six hourly intervals over 48 hours). Pelvic ultrasound, computed tomography and magnetic resonance imaging of adrenals were carried out when the biochemical findings suggested that there might be an autonomous source of androgen secretion.
\end{abstract}

Results-Clinical and laboratory assessments differentiated the patients into three diagnostic categories: adrenarche (18 cases), congenital adrenal hyperplasia (five cases), and adrenocortical tumour (two cases). The last had elevated concentrations of DHEAS, 1.5 and $19.1 \mu \mathrm{mol} / 1$ (normal value $<0.5 \mu \mathrm{mol} / \mathrm{l}$ ), androstenedione, 24.6 and $21.8 \mathrm{nmol} / 1$ (normal $<1 \mathrm{nmol} / \mathrm{l})$, and testosterone, 4.5 and $2.4 \mathrm{nmol} / 1$ (normal $<0.8 \mathrm{nmol} / \mathrm{l}$ ), with none suppressing on dexamethasone suppression. Congenital adrenal hyperplasia subjects had elevated basal serum concentrations of 17 OHP $(n=4): 250,140,14$, and $14.1 \mathrm{nmol} / 1$ (normal $<10 \mathrm{nmol} / \mathrm{l}$ ) and elevated peak values of 17 OHP after synacthen $(\mathrm{n}=3): 76,179.5$, and $175 \mathrm{nmol} / 1$. Adrenarche patients had elevated basal concentrations of DHEAS (median: $2.3 \mu \mathrm{mol} / 1 ; n=17)$ and androstenedione (median $2.6 \mathrm{nmol} / 1 ; \mathrm{n}=17$ ). Nine patients also had elevated basal serum testosterone concentrations (median $0.9 \mathrm{nmol} / \mathrm{l}$ ). Peak values of 17 OHP after synacthen were significantly different from baseline $(n=12)$ and were $<50 \%$ of the lowest value in congenital adrenal hyperplasia.
Serum DHEAS, androstenedione, and testosterone suppressed following dexamethasone suppression $(n=16)$, thereby distinguishing adrenarche patients from adrenal tumour patients. Clinical details did not distinguish patients, except for clitoromegaly which was present only in the tumour and congenital adrenal hyperplasia patients.

Conclusions-This protocol proved useful and practical in cases of virilisation presenting particular diagnostic difficulty.

(F Clin Pathol 1997;50:379-383)

Keywords: girls; virilisation; childhood

The most common cause of signs and symptoms of virilisation in girls during childhood is adrenarche, the onset of adrenal androgen secretion. ${ }^{12}$ This benign condition is part of normal development but in some children results in unwanted signs of virilisation such as pubic and axillary hair growth, acne, and body odour. These girls may subsequently be at risk of hirsutism, oligomenorrhea, polycystic ovary syndrome, and infertility. ${ }^{34}$ More serious causes of virilisation in early childhood are late presentation of congenital adrenal hyperplasia, ${ }^{5}$ or androgen secreting tumours of the adrenal cortex, ${ }^{6}$ or ovary ${ }^{7}$ and features of virilisation are always a major concern for parents. This paper analyses critically a protocol for investigation of virilisation in young girls which has evolved in our paediatric endocrine unit over the past 12 years.

\section{Methods}

SUBJECTS

Twenty five female patients aged from 1.6-8.7 years were referred with features of virilisation-pubic or axillary hair growth, acne, body odour, clitoromegaly, and advanced linear growth. Twenty four patients presented with pubic hair (20 were Tanner stage 2 and four were Tanner stage 3), eight had axillary hair (Tanner stage 2), 10 had tall stature (more than two standard deviations (2SD) greater than the mean for their age), seven had facial acne, and four had clitoromegaly. The one girl who did not have pubic or axillary hair was referred with body odour and acne.

\section{AUXOLOGY}

Height was measured using a Harpenden Stadiometer according to standard techniques. ${ }^{8}$ Pubertal development was staged according to 
Table 1 Diagnostic protocol for girls presenting with virilisation

\begin{tabular}{|c|c|}
\hline Type of assessment & Investigations \\
\hline Clinical & $\begin{array}{l}\text { Auxology of height, weight, } \\
\text { height velocity } \\
\text { Pubertal development, physica } \\
\text { examination for acne, } \\
\text { clitoromegaly, body odour }\end{array}$ \\
\hline Laboratory & $\begin{array}{l}\text { Basal serum concentrations of, } \\
\text { cortisol, } 17 \text { OHP, } \\
\text { androstenedione, DHEAS, } \\
\text { (oestradiol), testosterone } \\
\text { Short synacthen test } \\
\text { Low dose dexamethasone } \\
\text { suppression test }\end{array}$ \\
\hline Radiological & $\begin{array}{l}\text { Bone age } \\
\text { Ultrasound of ovaries } \\
\text { CT/MRI scan of adrenals }\end{array}$ \\
\hline
\end{tabular}

the criteria of Tanner. ${ }^{9}$ Bone age was assessed in 24 patients: the Tanner-Whitehouse (TW2 RUS) method ${ }^{10}$ was used in 21 patients and the Greulich and Pyle method ${ }^{11}$ was used in three patients. Height was converted to standard deviation scores.

\section{HORMONE ASSAYS}

Serum testosterone, androstenedione, and 17 $\mathrm{OH}$-progesterone (17OHP) were measured by radioimmunoassay after an initial solvent (ether) extraction followed by radioimmunoassay using ${ }^{125} \mathrm{I}$ ligand. The testosterone tracer was purchased from St Thomas's Hospital, London, the $17 \mathrm{OHP}$ tracer was purchased from Medgenix (Belgium), and the androstenedione tracer was prepared in-house. Antisera for each assay were prepared in-house. Dextran coated charcoal suspension was used to separate antibody bound and free hormone for testosterone and androstenedione, while a sepharose solid-phase second antibody was used for 17 OHP. Imprecision within and between assays was $8-10 \%$ and $8-12 \%$, respectively, for testosterone and androstenedione at the three concentrations used. Imprecision within and between assays was $4-8 \%$ and $5-8 \%$, respectively, for 17 OHP.

Dehydroepiandrosterone (DHEAS) was measured using an in-house non-extractive non-chromatographic radioimmunoassay using a ${ }^{125} \mathrm{I}$ tracer. Polyethylene glycol-assisted second antibody was used to separate antibody bound and free hormone. Imprecision within and between assays was $4-10 \%$ and $6-14 \%$, respectively. Oestradiol was measured using a double antibody direct assay commercial kit (DPC, Llanberis, North Wales). Cortisol was measured by a direct ${ }^{125} \mathrm{I}$ in-house radioimmunoassay. ${ }^{12}$ Imprecision within and between assays was $<8 \%$ at the three concentrations used.

\section{ENDOCRINE INVESTIGATIONS}

Dynamic endocrine tests (that is, the synacthen and low dose dexamethasone tests) were not performed in all subjects but, as the protocol evolved, they were performed in cases where basal hormones values did not give clear diagnostic information or in other cases of diagnostic difficulty.

The short synacthen test was performed in 16 subjects as follows: $0.25 \mathrm{mg}$ of synacthen were administered intramuscularly with blood sampling for cortisol, $17 \mathrm{OHP}$, androstenedione, DHEAS, and testosterone at 0,30 , and 60 minutes after administration of synacthen. The test was performed at 0900 , following $30 \mathrm{~min}$ utes' bed rest.

The low dose dexamethasone suppression test was performed in 16 subjects as follows: dexamethasone $(0.5 \mathrm{mg})$ was given orally every six hours for a total of eight doses starting at 0800 . Blood was obtained at 0 and 48 hours for cortisol, 17 OHP, androstenedione, DHEAS, and testosterone. The protocol of the low dose dexamethasone suppression test was the same as that used in our unit for investigation of children with Cushing's syndrome. ${ }^{13}$ Dexamethasone suppression was always performed after the short synacthen test had been completed.

DIAGNOSTIC PROTOCOL

The defined diagnostic protocol is shown in table 1 .

\section{STATISTICS}

Statistical analysis was carried out using descriptive statistics and paired Student's $t$ test when appropriate; $\mathrm{p}<0.05$ was considered significant. Data are expressed as individual and median values.

\section{Results}

DIAGNOSTIC CATEGORIES

Three clinical diagnostic categories were defined: virilisation due to adrenarche (18 cases), congenital adrenal hyperplasia (five cases), and adrenocortical tumour (two cases) (table 2).

BASAL SERUM HORMONE CONCENTRATIONS

Adrenarche

Median value and range for serum DHEAS concentrations $(\mathrm{n}=17)$ were $2.3 \mu \mathrm{mol} / \mathrm{l}$ and $0.3-4 \mu \mathrm{mol} / 1$, respectively. Sixteen patients had

Table 2 Clinical details of patients in diagnostic categories of adrenarche, congenital adrenal hyperplasia, and adrenocortical tumour

\begin{tabular}{|c|c|c|c|c|c|c|c|}
\hline & $\begin{array}{l}\text { Age range } \\
\text { (years) }\end{array}$ & $\begin{array}{l}\text { Pubic hair stage } \\
(n)\end{array}$ & $\begin{array}{l}\text { Axillary hair } \\
\text { stage }(n)\end{array}$ & Clitoromegaly & Acne & $\begin{array}{l}\text { Height } S D \\
\text { (range) }\end{array}$ & $\begin{array}{l}\text { Bone age } \\
\text { advance } \\
\text { (years) }\end{array}$ \\
\hline Adrenarche & $1.6-8.7$ & $\begin{array}{l}1(1) \\
2(14) \\
3(3)\end{array}$ & $\begin{array}{l}1(10) \\
2(8)\end{array}$ & $0 / 18$ & $3 / 18$ & $-1.1-3.4$ & $-1.3-4.0$ \\
\hline $\begin{array}{l}\text { Congenital adrenal } \\
\text { hyperplasia }\end{array}$ & $2.8-8.6$ & $\begin{array}{l}2(4) \\
3(1)\end{array}$ & $\begin{array}{l}1(4) \\
2(1)\end{array}$ & $3 / 5$ & $2 / 5$ & $0.1-3.1$ & $1.3-4.8$ \\
\hline $\begin{array}{l}\text { Adrenocortical } \\
\text { tumour }\end{array}$ & $6.7,1.7$ & $2(2)$ & $1(2)$ & $1 / 2$ & $2 / 2$ & $1.0-2.9$ & $2.2-2.3$ \\
\hline
\end{tabular}

Pubic and axillary hair growth is measured in Tanner stages; $\mathbf{n}=$ number of patients.

Height is expressed as standard deviations (SD) above or below the mean for age. 


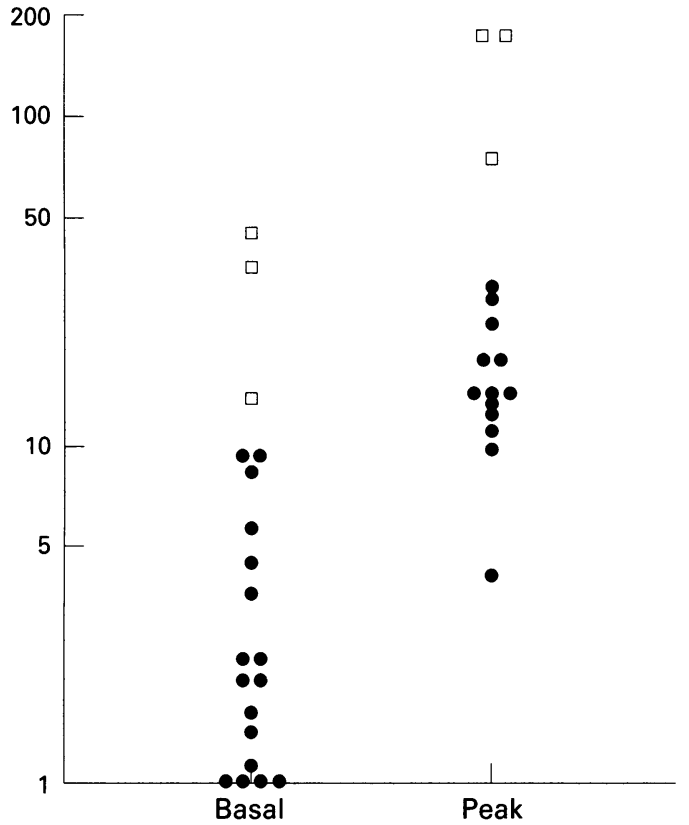

Figure 1 Basal and peak 17 OHP values after synacthen in patients with adrenarche $(\bullet)$, and congenital adrenal hyperplasia ( $\square$ ).

DHEAS concentrations above the upper limit of the normal range for age $(<0.5 \mu \mathrm{mol} / \mathrm{l})$. Median value and range for androstenedione concentrations $(n=18)$ were $2.6 \mathrm{nmol} / 1$ and $0.5-7.5 \mathrm{nmol} / 1$, respectively. Seventeen patients had androstenedione concentrations above the upper limit of the normal range for age $(<1.0 \mathrm{nmol} / \mathrm{l})$. Median value and range for $17 \mathrm{OHP}$ concentrations $(\mathrm{n}=17$ ) were $2 \mathrm{nmol} / 1$ and $0.9-10.9 \mathrm{nmol} / 1$, respectively (normal $<10 \mathrm{nmol} / \mathrm{l}$ ). Median value and range for testosterone $(\mathrm{n}=17)$ were $0.9 \mathrm{nmol} / 1$ and 0.5 $3.4 \mathrm{nmol} / \mathrm{l}$, respectively. Nine patients had testosterone concentrations above the upper limit of the normal range for age $(<0.8 \mathrm{nmol} / \mathrm{l})$. Oestradiol values $(\mathrm{n}=12)$ were $<20 \mathrm{nmol} / \mathrm{l}$ (normal prepubertal range $<20 \mathrm{nmol} / \mathrm{l}$ ).

Congenital adrenal hyperplasia

Serum DHEAS concentrations $(n=5)$ were $0.20,3.30,7.4,4.6$, and $5.1 \mu \mathrm{mol} / 1$ (normal $<0.5 \mu \mathrm{mol} / 1)$. Androstenedione concentrations $(\mathrm{n}=5)$ were $2,15.5,5.2,0.8$, and $45 \mathrm{nmol} / 1$ (normal $<1.0 \mathrm{nmol} / \mathrm{l}$ ). $17 \mathrm{OHP}$
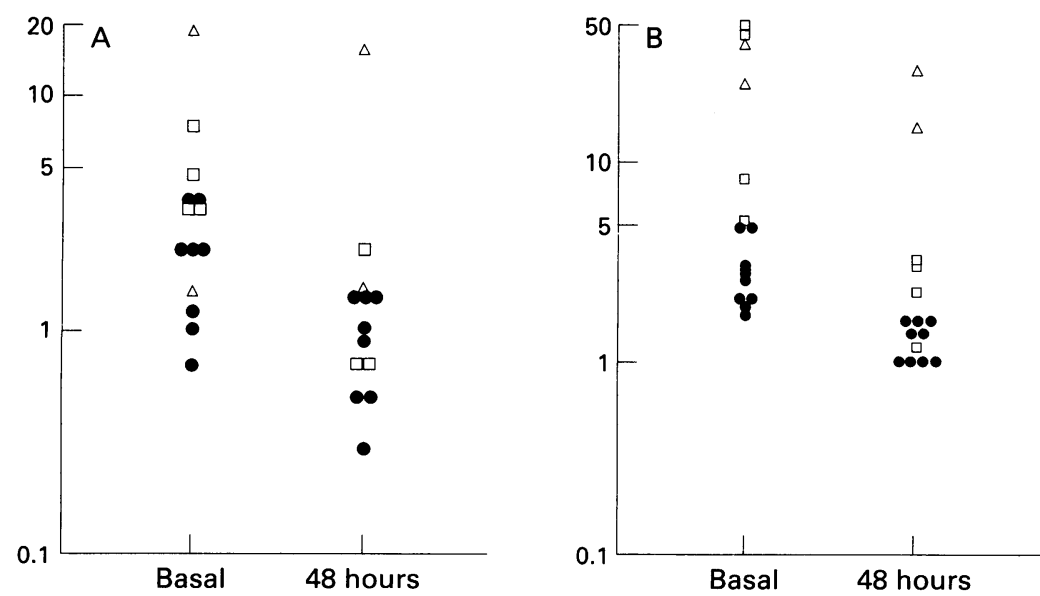

Figure 2 Basal and 48 hour values of $(A)$ DHEAS and $(B)$ androstenedione after dexamethasone suppression ( $0.5 \mathrm{mg}$, six hourly for 48 hours) in patients with adrenarche $(\bullet)$, congenital adrenal hyperplasia ( $(\square)$, and adrenal tumour $(\triangle)$. concentrations $(n=5)$ were elevated in four subjects: $250,140,14$, and $14.1 \mathrm{nmol} / 1$ (nor$\mathrm{mal}<10 \mathrm{nmol} / \mathrm{l})$ ), and normal in one subject $(4.9 \mathrm{nmol} / \mathrm{l})$. Testosterone values $(\mathrm{n}=3)$ were $9.2,3$, and $1.4 \mathrm{nmol} / 1$ and were elevated in all subjects (normal $0.8 \mathrm{nmol} / \mathrm{l}$ ). Oestradiol values $(\mathrm{n}=2)$ were $<20 \mathrm{nmol} / 1$ (normal $<20 \mathrm{nmol} / \mathrm{l}$ ).

\section{Adrenocortical tumour}

DHEAS concentrations were elevated in both subjects: 1.5 and $19.1 \mu \mathrm{mol} / 1$ (normal $<0.5 \mu \mathrm{mol} / \mathrm{l})$. Androstenedione was elevated in both subjects: 24.6 and $21.8 \mathrm{nmol} / 1$ (normal $<1.0 \mathrm{nmol} / \mathrm{l}$ ), as was testosterone: 4.5 and $2.4 \mathrm{nmol} / 1$ (normal $<0.8 \mathrm{nmol} / \mathrm{l}$ ). $17 \mathrm{OHP}$ values were normal. Oestradiol was measured in one patient at presentation and was $70 \mathrm{nmol} / 1$ (normal $<20 \mathrm{nmol}$ ).

\section{SHORT SYNACTHEN TEST}

Adrenarche

17 OHP concentrations $(\mathrm{n}=12)$ rose from a median of $1.8 \mathrm{nmol} / 1$ (range $0.9-9.4 \mathrm{nmol} / 1$ ) to a median of $14.3 \mathrm{nmol} / 1$ (range 4.1-30.6; $\mathrm{p}<0.001)$. Androstenedione concentrations $(\mathrm{n}=12)$ were median $2.6 \mathrm{nmol} / 1$ and range $0.5-7.4 \mathrm{nmol} / 1$ at baseline. After stimulation they were median $3.7 \mathrm{nmol} / \mathrm{l}$ and range $0.5-$ $7.8 \mathrm{nmol} / \mathrm{l}(\mathrm{p}=0.17)$.

\section{Congenital adrenal hyperplasia}

The patient with a normal basal 17 OHP concentration had elevated peak 17 OHP after synacthen $(175 \mathrm{nmol} / \mathrm{l})$. The two patients with slightly elevated basal values (14 and $14.1 \mathrm{nmol} / \mathrm{l}$ ) also had elevated peak values after synacthen (76 and $179.5 \mathrm{nmol} / \mathrm{l}$ ) (fig 1). Basal androstenedione concentrations were 15.5 , 5.2 , and $0.8 \mathrm{nmol} / 1$, increasing to 23,10 , and $4.3 \mathrm{nmol} / 1$, respectively, after synacthen.

Basal cortisol concentrations were 380,145 , and $670 \mathrm{nmol} / 1$ increasing to 650,547 , and $980 \mathrm{nmol} / \mathrm{l}$, respectively, after synacthen.

\section{Adrenal tumour}

Synacthen tests were not performed in these subjects.

LOW DOSE DEXAMETHASONE SUPPRESSION TEST Cortisol concentrations fell to less than $50 \mathrm{nmol} / 1$ after dexamethasone confirming that all patients complied well with medication and that androgen results could be interpreted correctly.

\section{Adrenarche}

Basal DHEAS concentrations $(\mathrm{n}=7)($ fig $2 \mathrm{~A}$ ) were median $2.1 \mu \mathrm{mol} / \mathrm{l}$, range $0.7-3.7 \mu \mathrm{mol} / \mathrm{l}$; they were suppressed to median $0.9 \mu \mathrm{mol} / \mathrm{l}$, range $0.3-1.5 \mu \mathrm{mol} / 1$ ( $\mathrm{p}<0.05)$. This suppression was at least $17 \%$ of basal values (average $54 \%)$. Androstenedione values $(\mathrm{n}=8)(\mathrm{fig} 2 \mathrm{~B})$ were median $2.5 \mathrm{nmol} / \mathrm{l}$, range $1.8-4.9 \mathrm{nmol} / \mathrm{l}$ and suppressed to median $1.3 \mathrm{nmol} / \mathrm{l}$, range $1.0-1.7 \mathrm{nmol} / 1 \quad(\mathrm{p}<0.01)$. This suppression was at least $39 \%$ of basal values (average $53 \%$ ). Serum testosterone $(n=6)$ values were median $1.0 \mathrm{nmol} / 1$, range $0.6-1.8 \mathrm{nmol} / 1$, and suppressed to median $0.5 \mathrm{nmol} / \mathrm{l}$, range $0.2-$ $1.2 \mathrm{nmol} / 1(\mathrm{p}<0.05)$. This suppression was at least $18 \%$ of basal values (average $55 \%$ ). 
Congenital adrenal hyperplasia

DHEAS concentrations $(\mathrm{n}=3)$ were $7.4,4.6$, and $3.2 \mu \mathrm{mol} / 1$ and suppressed to $0.72,2.2$, and $0.7 \mu \mathrm{mol} / \mathrm{l}$, respectively (fig $2 \mathrm{~A}$ ). This suppression was at least $52 \%$ of basal values. Androstenedione values $(n=4)$ were $50,8.4$, 5.1 , and $45 \mathrm{nmol} / 1$ and suppressed to $3.3,3.1$, 1.2 , and $2.3 \mathrm{nmol} / 1$, respectively (fig $2 \mathrm{~B}$ ). This suppression was at least $34 \%$ of basal values. Suppression of DHEAS and androstenedione did not differentiate between congenital adrenal hyperplasia and adrenarche. Serum testosterone $(\mathrm{n}=4)$ values were $9.2,1.9,1.5$, and $5.4 \mathrm{nmol} / \mathrm{l}$ at baseline, and suppressed to 1.7 , $0.96,0.7$, and $0.9 \mathrm{nmol} / 1$, respectively. This suppression was at least $50 \%$ of baseline values.

\section{Adrenocortical tumour}

DHEAS concentrations in the two patients were 1.5 and $19.1 \mu \mathrm{mol} / 1$ at baseline and 1.5 and $15.9 \mu \mathrm{mol} / 1$, respectively, after dexamethasone. Androstenedione values were 24.6 and $21.8 \mathrm{nmol} / 1$ at baseline and 29.2 and $15.4 \mathrm{nmol} / \mathrm{l}$, respectively, after dexamethasone. Testosterone values were 4.5 and $2.4 \mathrm{nmol} / \mathrm{l}$ at baseline and 1.7 and $2.3 \mathrm{nmol} / \mathrm{l}$, respectively, after dexamethasone. Apart from one girl in whom the testosterone values decreased by $37 \%$, the steroids were not suppressed after dexamethasone.

RADIOLOGICAL IMAGING

A pelvic ultrasound scan was performed on 12 patients and no significant ovarian abnormality was seen. Adrenal ultrasound was carried out in five patients and the results were normal in three. In two patients a left adrenal tumour and a right adrenal tumour were evidenced, respectively.

Six patients had an adrenal computed tomography. The two adrenal tumours were confirmed, and one other patient had bilateral adrenal hyperplasia. The scans in the remaining patients were normal.

\section{Discussion}

Virilisation in childhood is a relatively common complaint that may be caused by serious pathologies, such as an adrenal tumour or congenital adrenal hyperplasia, or by adrenarche-a normal physiological process. The cause of virilisation clearly has a direct consequence on management and this paper critically assesses a protocol for defining the aetiology of virilisation and describes its use in clinical practice.

Clinical assessment was generally of little use in diagnosis. The degree of advanced growth did not help define aetiology and neither did the degree of bone age maturation, although in adrenarche this is usually increased. ${ }^{2}$ Four of the five congenital adrenal hyperplasia patients however had marked advancement of skeletal maturation greater than three years. This is well described in late presentation of this condition ${ }^{14}$ and was usually greater than in the patients with adrenarche.

Clitoromegaly however did distinguish the groups, being absent in all the adrenarche patients but present in four out of seven girls with either congenital adrenal hyperplasia or adrenal tumour; these four girls were the ones with significantly elevated basal testosterone concentrations. However, genital enlargement is recognised as being a possible feature of atypical premature adrenarche. ${ }^{15}$ Similarly, acne occurred in only two of the 18 patients with adrenarche compared with four of the seven patients with congenital adrenal hyperplasia or a tumour.

In all the patients, pubic hair was the most common presenting feature, accompanied sometimes by axillary hair and body odour. Premature adrenarche occurred mainly in the 3-8 year age group as reported in the literature. $^{16}$

Therefore, clinical and auxological features could not clearly distinguish between these three categories and laboratory and radiological imaging tests were necessary to make a definite diagnosis. Measurement of basal androgens and 17 OHP concentrations were helpful as markedly elevated serum $17 \mathrm{OHP}$, DHEAS, androstenedione, or testosterone concentrations often suggested congenital adrenal hyperplasia or a tumour.

Adrenarche patients present a wide range of basal androgen values. According to the literature those with the most increased basal serum androstenedione and DHEAS are the ones that should be most closely followed up as they appear to develop functional ovarian hyperandrogenism more frequently. ${ }^{23}{ }^{15}$ Elevated basal serum DHEAS concentrations in 16 of our 18 adrenarche patients were compatible with Tanner stage 2 for pubic hair. ${ }^{17}$

In girls presenting with virilisation there is much discussion as to whether a short synacthen test should be performed, considering that 21 hydroxylase deficiency may occur rather frequently in some populations. ${ }^{14}{ }^{17} 18 \mathrm{In}$ our series, of the five patients with congenital adrenal hyperplasia, one had a normal and two had marginally elevated basal $17 \mathrm{OHP}$ values. In these patients the degree of 17 OHP response to synacthen clearly distinguished them from those with adrenarche. Measurement of androstenedione, however, during the synacthen test was not a helpful discriminator.

In the virilising adrenocortical tumours, androstenedione showed the most significant elevation, as reported previously. ${ }^{19}$ All patients with tumours had elevated basal androgens. Elevation of DHEAS is also an indication that a tumour may be present.

All patients with adrenarche that were tested with the low dose dexamethasone suppression test showed some suppression of the steroids as reported by Temeck. ${ }^{20}$ This did not occur in the patients with adrenocortical tumours.

In conclusion, no clinical or auxological feature can be considered as an exact indicator of a specific condition. If clitoromegaly or acne occur in addition to pubic hair, there is an increased risk of congenital adrenal hyperplasia or an adrenal tumour. Basal hormonal concentrations should be measured as a first approach to any case of virilisation, particularly $17 \mathrm{OHP}$, DHEAS, androstenedione, and testosterone. 
Stimulation and suppression tests should subsequently be performed. If an adrenal tumour is suspected (from clinical observations or basal hormone values), an adrenal CT or MRI scan should then be performed. The protocol we have described has proved useful and practical. Although it may not be indicated for every case of virilisation, we recommend its use in cases presenting diagnostic difficulty.

1 Siegel SF, Finegold DN, Urban MD, McVie R, Lee PA Premature adrenarche: etiological heterogeneity. $f$ Clin Endocrinol Metab 1992;74:239-47.

2 Ibañez L, Virdis R, Potau N, Zampolli M, Ghizzoni L Albisu MA, et al. Natural history of premature pubarche: an auxological study. ₹ Clin Endocrinol Metab 1992;74:254-7.

3 Ibañez L, Potau N, Virdis R, Zampolli M, Terzi C, Gussinye $\mathrm{M}$, et al. Postpubertal outcome in girls diagnosed of premature pubarche during childhood: increased frequency of functional ovarian hyperandrogenism. $f$ Clin Endocrinol Metab 1993;76:1599-603.

4 Rosenfield R. Hyperandrogenism in peripubertal girls. Pediatr Clin North Am 1990;37:1333-58.

5 Azziz R, Dewailly D, Owerbach D. Clinical review 56. Nonclassical adrenal hyperplasia: current concepts. $f$ Clin Endocrinol Metab 1994;78:810-5.

6 Gabrilove JL, Seman AT, Sabet R, Mitty HA, Nicolis GL. Virilising adrenal adenoma with studies on the steroid content of adrenal venous effluent and a review of the tent of adrenal venous effluent and a
literature. Endocrinol Rev 1981;2:462-70.

7 Fleetwood JA, Watson MJ, Wastell HJ, Weddell A. Hormon studies in a case of virilisation due to ovarian tumour. $A n n$ Clin Biochem 1985;22:498-501.
8 Cameron $\mathrm{N}$. The methods of auxological anthropometry. In: Falkner F, Tanner JM, eds. Human growth. New York Plenum, 1978:35-87.

9 Tanner JM. The development of the reproductive system. In: Growth at adolescence, 2nd edn. Oxford: Blackwell Scientific Publications, 1962:28-39.

10 Tanner JM, Whitehouse RH, Marshall WA, Healy MJR Goldstein H. Assessment of skeletal maturity and prediction of adult height (TW2 method). London: Academic press, 1975.

11 Greulich WW, P.yle SI. Radiographic atlas of skeletal development of the hand and wrist. Stanford: Stanford University Press, 1966.

12 Cunnah D, Jessop DS, Besser GM, Res LH. Measurement of circulating corticotrophin-releasing factor in man. $f$ Endocrinol 1987;113:123-31.

13 Weber A, Trainer PJ, Grossman AB, Afshar F, Medbak S Perry LA, et al. Investigation, management and therapeutic outcome in 12 cases of childhood and adolescent Cushing's syndrome. Clin Endocrinol 1994;43:19-27.

14 Dewailly D, Vantyghem-Haudiquet MC, Sainsard C, Buvet $\mathrm{J}$, Cappoen JP, Ardaens $\mathrm{K}$, et al. Clinical and biological phenotypes in late-onset 21-hydroxylase deficiency. 7 Clin Endocrinol Metab 1986;63:418-23.

15 Saenger P. Premature adrenarche: a normal variant of puberty?. F Clin Endocrinol Metab 1992;74:236-8.

16 Pang S. Premature adrenarche. Pediatr Adolesc Endocrinol 1984;13:173-84.

17 Balducci R, Boscherini B, Mangiantini A, Morellini M, Toscano V. Isolated precocious pubarche: an approach. Clin Endocrinol Metab 1994;79:582-9.

18 Azziz R, Zacur HA. 21-hydroxylase deficiency in female hyperandrogenism: screening and diagnosis. 7 Clin Endocrinol Metab 1989;69:577-84.

19 Honour IN, Price DA, Tanner NF, Warden HB, Grant DB. Steroid biochemistry of virilizing adrenal tumours in childhood. Eur $\mathcal{F}$ Pediatr 1984;142:165-9.

20 Temeck JW, Pang S, Nelson C, New MI. Genetic defects of steroidogenesis in premature pubarche. $\mathcal{f}$ Clin Endocrinol Metab 1987;64:609-17. 